\title{
PENGARUH ZAT BESI DAN VITAMIN C TERHADAP PERUBAHAN KADAR HEMOGLOBIN IBU HAMIL
}

\author{
Sri Sartika Sari Dewi ${ }^{1)}$, Novita Sari Batubara ${ }^{2)}$ \\ srisartikasari82@gmail.com \\ ${ }^{1,2)}$ STIKes Aufa Royhan Padangsidimpuan \\ Jalan Raja Inal Siregar Kel. Batunadua Julu, Kota Padangsidimpuan 22733,Sumatera Utara, \\ Indonesia
}

\begin{abstract}
Pregnancy is a period of considerable changes in women's body. One of the changes is one of the changes is in hematological process in hematologic process, such as increasing maternal blood volume, decreaseing hemoglobin and hematocrit, also increasing in iron demand. The purpose of this study is to know the effect of iron and vitamin $C$ to the changes of hemoglobin levels in pregnant women.This study was the intervention study (intervention trial) with the design of one group pretest-posttest.This study was conducted in the region of Lubuk Buaya Health Care from 6 March until 21 April. The sample was 20 pregnant womenfirst and third trimester with Hb levels $\leq$ $11 \mathrm{gr} / \mathrm{dl}$ divided into 2 treatment group.The Hb levels examination conducted at the laboratory of Lubuk Buaya Health Care with Cyanmethemoglobin methods using calibrated Photometer. The data was analyzed by using paired T test and oneway anova. The results showed that the Group A (iron) average levels of $\mathrm{Hb}$ before treatment was $9.93 \mathrm{gr} / \mathrm{dl}$ and increased to $11.15 \mathrm{gr} / \mathrm{dl}$, Group $B$ (vit $C+$ iron) average $\mathrm{Hb}$ levels before treatment was $9.64 \mathrm{gr} / \mathrm{dl}$ and increased to $11.28 \mathrm{gr} / \mathrm{dl}$. There is a significant increase in Hb levels before and after the administration of supplement on all treatment groups.
\end{abstract}

Keywords: Iron, Vitamin C, Hemoglobin

\begin{abstract}
Abstrak
Selama kehamilan terjadi beberapa perubahan adaptasi dalam tubuh. Salah satu perubahan yang terjadi adalah perubahan hematologis, berupa peningkatan volume darah, penurunan hemoglobin dan hematokrit, serta peningkatan kebutuhan Fe. Vitamin C sangat membantu penyerapan besi non heme dengan mereduksi besi ferri menjadi ferro dalam usus halus sehingga mudah diabsorpsi. Tujuan penelitian ini untuk mengetahui pengaruh Zat Besi dan vitamin C terhadap perubahan hemoglobin ibu hamil. Penelitian ini merupakan penelitian intervensi dengan desain one grup pretest dan posttest. Penelitian dilakukan di Puskesmas Lubuk Buaya, pada tanggal 06 Maret - 21 April, terhadap 20 orang ibu hamil trimester I dan trimester II, kadar Hb $\leq 11$ gr/dl dibagi menjadi 2 kelompok perlakuan. Pemeriksaan Hb dilakukan di Laboratorium Puskesmas Lubuk Buaya dengan metode Cyanmethemoglobin dengan alat Photometer yang telah dikalibrasi. Pengolahan dan analisis data menggunakan uji Paired T Test, dilanjutkan uji Oneway Anova. Hasil penelitian menunjukkan kelompok A ( Zat Besi) rerata Hb sebelum perlakuan 9,93 gr/dl meningkat menjadi 11,15 gr/dl, kelompok B (Zat Besi + vit C) rerata kadar Hb sebelum perlakuan 9,64 gr/dl meningkat menjadi 11,28 gr/dl. Terdapat peningkatan Hb yang signifikan sebelum dan setelah pemberian suplementasi pada semua kelompok perlakuan.
\end{abstract}

Kata kunci: Zat Besi, Vitamin C, Hemoglobin

\section{Pendahuluan}

Selama proses kehamilan terjadi beberapa perubahan adaptasi dalam tubuh ibu. Salah satu perubahan yang terjadi adalah perubahan hematologis, berupa peningkatan volume darah ibu, penurunan hemoglobin dan hematokrit, peningkatan kebutuhan zat besi, perubahan pada sistem imunologis dan leukosit, serta koagulasi dan fibrinolisis. ${ }^{[2]}$ 
Terjadinya kehamilan, ibu hamil akan mengalami kekurangan zat besi karena volume sirkulasi darah dan peningkatan kebutuhan besi terbagi untuk janin yang dikandungnya. Kekurangan zat besi yang terjadi secara terus menerus akan menyebabkan gangguan eritropoesis, seperti kadar hemoglobin menurun yang diikuti oleh gejala dan tanda klinis anemia. ${ }^{[3,4]}$

Kebutuhan ibu pada saat hamil terhadap unsur-unsur makanan semakin meningkat seperti protein, zat besi, vitamin, asam folat dan mineral. Jika kebutuhan tersebut tidak tercukupi, maka ibu akan mengalami anemia. Anemia yang sering dialami ibu hamil adalah anemia defisiensi besi dan anemia megaloblastik. ${ }^{[2.6]}$

Kebutuhan zat besi dalam kehamilan meningkat untuk pembentukan plasenta dan sel darah merah serta persiapan darah yang akan hilang pada saat melahirkan. Peningkatan kebutuhan zat besi ini bisa mencapai 100-300\%. Kekurangan zat besi pada ibu hamil dapat mengakibatkan anemia, partus lama dan perdarahan post partum. ${ }^{[7]}$

Tablet besi yang umum digunakan dalam suplementasi zat besi adalah ferrosus sulfat, senyawa ini tergolong murah dan dapat diabsorbsi sampai $20 \%$. Vitamin $\mathrm{C}$ dan zat besi membentuk senyawa askorbat besi kompleks yang mudah larut dan mudah diabsorpsi. Vitamin C sangat membantu penyerapan besi non heme dengan mereduksi besi ferri menjadi ferro dalam usus halus sehingga mudah diabsorpsi. Vitamin C menghambat pembentukan hemosiderin yang sukar dimobilisasi untuk membebaskan besi bila diperlukan. Dengan demikian resiko anemia defisiensi zat besi bisa dihindari. [8]

\section{Metode Penelitian}

Penelitian ini merupakan penelitian intervensi (intervention trial) dengan desain one group pretest-posttest. Penelitian ini dilakukan di Puskesmas Lubuk Buaya pada tanggal 06 Maret -
21 April, terhadap 20 orang ibu hamil dengan trimester I dan trimester II, dan kadar $\mathrm{Hb} \leq 11$ gr/dl yang dibagi menjadi 2 kelompok perlakuan. 10 orang untuk perlakuan pertama dan 10 orang untuk perlakuan kedua. Pemeriksaan kadar Hb dilakukan di Laboratorium Puskesmas Lubuk Buaya dengan metode Cyanmethemoglobin dengan alat Photometer yang telah dikalibrasi.

Populasi sampel adalah semua ibu hamil yang datang untuk memeriksakan kehamilan ke Puskesmas Lubuk Buaya Kota Padang. Pengolahan dan analisis data menggunakan uji Paired T Test, dilanjutkan dengan uji Oneway Anova.

\section{Hasil dan Pembahasan}

Tabel 1 Kadar Hemoglobin Sebelum dan Setelah Perlakuan pada Kelompok A

\begin{tabular}{lcccc}
\hline Kadar Hb & $\begin{array}{c}\text { Jumlah } \\
\text { Sampel }\end{array}$ & $\begin{array}{c}\text { Rerata } \\
(\mathrm{gr} / \mathrm{dl})\end{array}$ & $\begin{array}{c}\text { Standar } \\
\text { Deviasi }\end{array}$ & $\begin{array}{c}\text { Nilai } \\
\mathrm{p}\end{array}$ \\
\hline Sebelum & 10 & 9.93 & 0.655 & \\
Setelah & 10 & 11.15 & 0.726 & 0.001 \\
Delta $\mathrm{Hb}$ & 10 & 1.22 & 0.674 & \\
\hline
\end{tabular}

Tabel diatas menunjukkan bahwa rerata kadar $\mathrm{Hb}$ sebelum perlakuan $9.93 \mathrm{gr} / \mathrm{dl}$ meningkat menjadi $11.15 \mathrm{gr} / \mathrm{dl}$ dengan rerata selisih peningkatan kadar $\mathrm{Hb}$ sebesar $1.22 \mathrm{gr} / \mathrm{dl}$. Berdasarkan hasil uji statistik diperoleh nilai $\mathrm{p}=0.001$ $(\mathrm{p}<0.05)$, sehingga disimpulkan ada pengaruh pemberian Zat Besi terhadap peningkatan kadar $\mathrm{Hb}$.

Tabel 2 Kadar Hemoglobin Sebelum dan Setelah Perlakuan pada Kelompok B

\begin{tabular}{lcccc}
\hline $\begin{array}{c}\text { Kadar } \\
\mathrm{Hb}\end{array}$ & $\begin{array}{c}\text { Jumlah } \\
\text { Sampel }\end{array}$ & $\begin{array}{c}\text { Rerata } \\
(\mathrm{gr} / \mathrm{dl})\end{array}$ & $\begin{array}{c}\text { Standar } \\
\text { Deviasi }\end{array}$ & $\begin{array}{c}\text { Nilai } \\
\mathrm{p}\end{array}$ \\
\hline Sebelum & 10 & 9.64 & 0.688 & \\
Setelah & 10 & 11.28 & 0.649 & 0.001 \\
Delta Hb & 10 & 1.64 & 0.554 & \\
\hline
\end{tabular}

Tabel diatas menunjukkan bahwa rerata kadar $\mathrm{Hb}$ sebelum perlakuan $9.64 \mathrm{gr} / \mathrm{dl}$ meningkat menjadi $11.28 \mathrm{gr} / \mathrm{dl}$ dengan rerata selisih peningkatan kadar $\mathrm{Hb}$ sebesar $1.64 \mathrm{gr} / \mathrm{dl}$. Berdasarkan hasil uji 
statistik diperoleh nilai $\mathrm{p}=0.001$ $(\mathrm{p}<0.05)$, sehingga disimpulkan ada pengaruh pemberian Zat Besi + Vit. C terhadap peningkatan kadar $\mathrm{Hb}$.

Tabel 3 Peningkatan dan Analisis Perbandingan Kadar Hemoglobin Menurut Kelompok Perlakuan

\begin{tabular}{clccc}
\hline & & $\mathrm{n}$ & $\begin{array}{c}\text { Rerata } \pm \text { SD } \\
(\mathrm{gr} / \mathrm{dl})\end{array}$ & Nilai $\mathrm{p}$ \\
\hline Kadar & $\mathrm{Fe}$ & 10 & $1,22 \pm 0,674$ & $<0,001$ \\
$\mathrm{Hb}$ & $\mathrm{Fe}+$ Vit. & 10 & $1,64 \pm 0,554$ & $<0,001$ \\
& $\mathrm{C}$ & & & \\
\hline
\end{tabular}

Tabel diatas menunjukkan bahwa perbedaan kenaikan $\mathrm{Hb}$ terlihat sangat signifikan, dimana perlakuan pada kelompok B (suplementasi Zat Besi + Vit. C) kadar $\mathrm{Hb}$ meningkat menjadi $1.64 \mathrm{gr} / \mathrm{dl}$. Hal ini terbukti lebih efektif dibandingkan kenaikan $\mathrm{Hb}$ pada kelompok perlakuan A (suplementasi Zat Besi) kadar Hb 1.22 gr/dl.

Hasil penelitian menunjukkan bahwa rerata kadar $\mathrm{Hb}$ kelompok $\mathrm{A}$ (suplementasi Zat Besi) sebelum perlakuan adalah $9.93 \mathrm{gr} / \mathrm{dl}$ dengan standar deviasi 0.655 dan mengalami peningkatan kadar $\mathrm{Hb}$ setelah diberikan suplementasi Zat Besi yaitu 11,15 gr/dl dengan standar deviasi 0.726. Terdapat perbedaan rerata kadar $\mathrm{Hb}$ sebelum dan setelah perlakuan sebesar $1.22 \mathrm{gr} / \mathrm{dl}$ dengan standar deviasi 0.674 . Berdasarkan hasil uji statistik diperoleh nilai $p=0.001 \quad(p<0,05)$, sehingga disimpulkan ada pengaruh pemberian Zat Besi terhadap peningkatan kadar Hb. Hasil penelitian ini sejalan dengan penelitian Murni (2014), yaitu ada perbedaan yang signifikan antara kadar $\mathrm{Hb}$ ibu hamil sebelum dan sesudah pemberian $\mathrm{Fe}$. Rerata kadar $\mathrm{Hb}$ pada pengukuran pertama 10.61 gr\% dengan standar deviasi 1.63 gram $\%$ dan pada pengukuran kedua 10.93 gr\% dengan deviasi 1.51 dan perbedaan nilai mean kadar $\mathrm{Hb}$ antara pengukuran pertama dan kedua yaitu 0.32 dengan standar deviasi 0.26. Hasil uji statistik didapatkan nilai $\mathrm{p}=0,000(<0,05) .{ }^{[10]}$

Keterkaitan antara zat besi dengan kadar $\mathrm{Hb}$ dapat dijelaskan bahwa zat besi merupakankomponen utama yang memegang peranan penting dalam pembentukan darah (hemopoiesis), yaitu mensintesis hemoglobin. Sehingga dengan adanya pemberian suplementasi zat besi dalam tubuh dapat meningkatkan kadar $\mathrm{Hb}$.

Hasil penelitian menunjukkan bahwa rerata kadar $\mathrm{Hb}$ kelompok $\mathrm{B}$ (suplementasi Zat Besi + Vitamin C) sebelum perlakuan adalah $9.64 \mathrm{gr} / \mathrm{dl}$, mengalami peningkatan kadar $\mathrm{Hb}$ setelah diberi suplementasi Fe + Vitamin $\mathrm{C}$ yaitu $11.28 \mathrm{gr} / \mathrm{dl}$. Terdapat perbedaan rerata kadar $\mathrm{Hb}$ sebelum dan sesudah perlakuan sebesar $1.64 \mathrm{gr} / \mathrm{dl}$. Berdasarkan hasil uji statistik diperoleh nilai $p=0.001 \quad(p<0,05)$, sehingga disimpulkan ada pengaruh pemberian $\mathrm{Fe}$ + Vit. C terhadap peningkatan kadar $\mathrm{Hb}$. Hasil penelitian didukung dengan penelitian lain yang menyatakan terdapat peningkatan kadar $\mathrm{Hb}$ setelah diberikan suplementasi $\mathrm{Fe}$ dan vitamin $\mathrm{C}$ dari rerata kadar $\mathrm{Hb} 10.1$ gr\% sebelum pemberian suplementasi menjadi rerata kadar $\mathrm{Hb} 12.7$ gr\%setelah pemberian suplementasi dengan rerata peningkatan kadar $\mathrm{Hb} 2.7$ gr\%. ${ }^{[12]}$

Hasil penelitian ini juga sejalan dengan penelitian lain dengan hasil pemberian tablet $\mathrm{Fe}$ dan vitamin $\mathrm{C}$ selama 30 hari kepada 25 responden diperoleh rerata kadar $\mathrm{Hb}$ pada pre test sebesar 10.66 gr\% dan meningkat menjadi $11.11 \mathrm{gr} \%$. Berdasarkan hasil uji statistik dengan menggunakan uji paired sample test diperoleh nilai $\mathrm{p}=0.001 \quad(\mathrm{p}<0,05)$, sehingga disimpulkan ada pengaruh pemberian tablet $\mathrm{Fe}$ dan vitamin $\mathrm{C}$ terhadap peningkatan kadar Hb. ${ }^{[13]}$

Pemberian suplementasi zat besi kepada ibu hamil memang dapat membantu meningkatkan kadar $\mathrm{Hb}$, akan tetapi lebih efektif jika diberikan bersamaan dengan vitamin $\mathrm{C}$, karena dapat membantu penyerapan zat besi didalam tubuh.

Perbedaan kenaikan $\mathrm{Hb}$ terlihat sangat signifikan antara kedua kelompok perlakuan. Perlakuan pada kelompok B (Suplementasi Zat Besi + Vitamin C) lebih efektif dalam meningkatkan kadar 
$\mathrm{Hb}$ dibandingkan kelompok perlakuan A (suplementasi Zat Besi).

\section{Kesimpulan}

Terdapat pengaruh pemberian zat besi terhadap peningkatan kadar hemoglobin ibu hamil. Terdapat pengaruh pemberian zat besi dan vitamin $\mathrm{C}$ terhadap peningkatan kadar hemoglobin ibu hamil. Terdapat perbedaan peningkatan kadar $\mathrm{Hb}$ yang signifikan antara kedua kelompok perlakuan. Kelompok perlakuan yang memiliki pengaruh lebih efektif dalam meningkatkan kadar $\mathrm{Hb}$ ibu hamil adalah kelompok perlakuan B (Suplementasi Zat Besi + Vitamin C).

\section{Daftar Pustaka}

[1] Manuaba, IAC. Manuaba, Ida BGF," Manuaba, IBG. Ilmu Kebidanan, Penyakit Kandungan dan KB. Jakarta. EGC; 2012

[2] Cunningham, FG, Leveno, KJ, Bloom, LS, Hauth, JC, Rouse, DJ, and Spong, CY. William Obstetrics 23th Edition, Vol 1. New York : Mc Graw Hill Education ; 2013

[3] Wiknjosastro, H. Ilmu Kebidanan. Jakarta. Yayasan Bina Pustaka; 2007

[4]Bakta, IM, Suega, K, Dharmayuda, TG. Anemia Defisiensi Besi. Dalam : Buku Ajar Ilmu Penyakit Dalam Jilid II Edisi IV. Editor : Sudoyo, AW. Jakarta. Pusat Penerbitan Departemen Ilmu Penyakit Dalam. Fakultas Kedokteran Universitas Indonesia; 2006

[5] Arisman. Buku Ajar Ilmu Gizi. Gizi dalam Daur Kehidupan. Jakarta. EGC ; 2009

[6] Moehji, S. Ilmu Gizi 1, Pengetahuan Dasar Ilmu Gizi.. Jakarta. Bhratara Niaga Media ; 2002

[7]Lailiyana, Noor, N, Suryatni. Buku Ajar Gizi Kesehatan Reproduksi. Jakarta. EGC ; 2010

[8] Argana, G, Kusharisupeni, Utari, DM. "Vitamin C sebagai Faktor Dominan untuk Kadar Haemoglobin pada Wanita Usia 20 - 35 Tahun". Jakarta. Jurnal Kedokteran Trisakti. 2004. 23 ( 1).
[9] Sastroasmoro, S, and Ismael, S. Dasar - dasar Metodologi Penelitian Klinis Edisi Ke-4. Jakarta. Sagung Seto ; 2011

[10] Murni, H. Perbedaan Kadar Hb dalam Pemberian Tablet Fe pada Ibu Hamil di Wilayah Kerja puskesmas Pakan Kamis Kabupaten Agam. Padang Jurnal Sehat Mandiri Jilid 9 Nomor $1 ; 2014$

[11] Wibowo, MFA. Pengaruh Suplementasi Tablet Besi dan Vitamin C terhadap Peningkatan Kadar Hemoglobin pada Siswa Kelas VI SDN Klego 01 Kota Pekalongan. Skripsi. Jurusan Ilmu Kesehatan Masyarakat Fakultas Ilmu Keolahragaan Universinas Negeri Semarang ; 2014

[12] Kadafi, M. Pengaruh Pemberian Tablet Besi dan Vitamin C terhadap Kadar Hemoglobin Mahasiswa S1 eperawatan Universitas Muhammadiyah Surakarta. Naskah publikasi. Surakarta: Fakultas Ilmu Kesehatan. Universitas Muhammadiyah Surakarta ; 2015

[13] Indriani, Y, Khomsan, A, Sukandar, D, Riyadi, H, Zuraida, R. Pengaruh Pemberian Zat Besi dan Asam Folat Dibandingkan dengan Mutivitamin dan mineral pada Pekerja Wanita Usia Subur di Agroindustri Nanas. Makara Seri Kesehatan.17(1): In Press DOI ; 201. 